\title{
Effects of Night-heating of Fruit on Cell Size and Sucrose Accumulation in the Outer Portion of Watermelon (Citrullus lanatus Matsum. et Nakai)
}

\author{
Yasutaka Kano ${ }^{1}$ \\ Ishikawa Prefectural University, Bioproduction Science, Suematsu 1-308, \\ Nonoichi, Ishikawa 921-8836, Japan
}

\section{Youichi Ikeshita, Yuri Kanamori, and Nobuyuki Fukuoka \\ Ishikawa Agricultural Research Center}

Additional index words. Citrullus lanatus Matsum. et Nakai, heating fruit during night, sugar accumulation, watermelon

\begin{abstract}
To investigate the effects of night temperature on sugar accumulation in watermelon fruit, fruits were treated with higher nighttime temperature under a greenhouse. The minimum nighttime ambient temperature of the heating box $\left(18{ }^{\circ} \mathrm{C}\right)$ was $\approx 6{ }^{\circ} \mathrm{C}$ higher than that of the control. The heat-treated fruit weighed at the end of heating treatment, 16 days after anthesis (DAA), was greater than that of control, but fruit weight at harvesting, 42 DAA, was almost the same in both treatments. Cells of all portions of the heat-treated fruit at 16 DAA were much larger than those of the control, and cells in the outermost rectangular parallelepipeds (RPs; 15-mm long samples that were serially collected from a $10-\mathrm{mm}$ thick disk along a $10-\mathrm{mm}$ wide strip removed at the maximum transverse diameter of the fruit) of the heat-treated fruit were $80 \mu \mathrm{m}$ or more larger than those of the control. At 16 DAA, the number of RPs with sucrose contents of $2 \mathrm{~g} \cdot \mathrm{L}^{-1}$ or more were six and nine in control and heat-treated fruit, respectively. At 42 DAA, content in the outer RPs of the heat-treated fruit was greater than that in the outer RPs of the control. The number of RPs with sucrose contents of $40 \mathrm{~g} \cdot \mathbf{L}^{-1}$ or more was five in the control and 11 in heat-treated fruit. Mean sucrose, glucose, and fructose in fruit at 16 DAA did not differ in the treated fruit from the control. However, the sucrose content of heat-treated fruit was $32 \%$ higher than that of the control at 42 DAA. Glucose and fructose content were lower in heat-treated fruit than in the control.
\end{abstract}

Most vegetables in Ishikawa Prefecture, Japan, are produced by growers in the sand dune areas of Kanazawa City. Watermelon is one of the most important vegetables in Ishikawa Prefecture. However, in watermelons grown under plastic film greenhouses and shipped in early summer, only the central portion measuring $10 \mathrm{~cm}$ in diameter is red and sweet; the portion extending from the central portion to the white rind, which also is red, is not sweet. In this type of cultivation, the minimum temperature during early fruit development declines to nearly $10{ }^{\circ} \mathrm{C}$. Glucose and fructose contents in watermelon fruit are almost constant during fruit development, but sucrose content increases rapidly at $30 \mathrm{~d}$ after anthesis (DAA) (Elmstrom and Davis, 1981). This result shows that sucrose content is one of the most important factors determining fruit sweetness. When melon fruit was treated with higher temperature, sucrose accumulates abruptly after 30 DAA (Kano, 2006) and fruit sucrose content increases as a result of early cell expansion

Received for publication 10 Jan. 2008. Accepted for publication $17 \mathrm{Feb} .2008$.

${ }^{1}$ To whom reprint requests should be addressed; e-mail gansho@ishikawa-pu.ac.jp
(Kano, 2006) or auxin (Kano, 2002). From these results, we surmise that the reason for the lack of sweetness in the outer portion of watermelon fruit is the low sucrose content of the outer portion owing to the suppression of cell enlargement by lower nighttime temperature during early fruit development.

Therefore, watermelon fruits were treated with higher nighttime temperature to determine the effect on sucrose content in the outer portion of the fruit.

\section{Materials and Methods}

Plant materials. Watermelon (Citrullus lanatus Matsumu. Et Nakai, cv. Tsukuba no Kaori) was grown under a plastic film greenhouse at Ishikawa Agricultural Research Center. Plants were grown $40 \mathrm{~cm}$ apart in rows $300 \mathrm{~cm}$ wide. Pinching was done at the four-true leaf stage of the primary vines, and two secondary vines were kept. Flowers opened on 17 May 2007 and were set at the 20th node of each vine and one fruit was left on each stock. A fruitlet was put in a $30-\mathrm{cm}$ cube wooden box (Fig. 1) from 23 May to 1 June.

Heating apparatus and temperature measurement. The box was cut $10 \mathrm{~cm}$ from the base, and the lower third of the box was used for heating the fruit. Sand was poured to $3 \mathrm{~cm}$ depth in the bottom and an electric cable to create a hotbed (equivalent to $7.7 \mathrm{~W}$ ) was set on the sand and covered with a further $2 \mathrm{~cm}$ of sand. The fruit was covered with the upper two-thirds of the box at $1700 \mathrm{HR}$ and uncovered at $0700 \mathrm{HR}$ each day for $10 \mathrm{~d}$ from 23 May to 1 June (designated as heat treatment). The electric current was turned on $1700 \mathrm{HR}$ and turned off at $0700 \mathrm{HR}$. Temperatures inside and outside the heating box for watermelon fruit, itself located at away from the extremities of the plastic film greenhouse, were measured using a thermo recorder equipped with thermistors called "Ondotori" in Japanese (TR-71S; T and D, Matsumoto, Japan) from 6 DAA (23 May) to 16 DAA (1 June). Temperatures every hour from $1700 \mathrm{HR}$ to $0700 \mathrm{HR}$ during heat treatment were illustrated.

Measurements of cell size in the fruit. Three fruits were collected at 16 DAA, 1 June, and at 42 DAA, 27 June. Two 20-mm thick disks were cut from three fruit for each treatment. One disk was taken from the maximum transverse diameter toward the calyx end for cell analysis and the other from the maximum transverse diameter toward the peduncle end for sugar analysis. Using a sharp table knife, one strip, a sample measuring $\approx 10 \mathrm{~mm} \times 10 \mathrm{~mm}$, was removed from the disk centered on the diameter line of each disk (Fig. 2). Rectangular parallelepipeds (RP), each measuring $\approx 15 \mathrm{~mm}$, were serially sampled across the diameter of the disk using the same sharp table knife. The third and fourth RPs from the left and right end and two central RPs of the fruits 16 DAA were used for cell analysis. The RPs were dehydrated using a gradient of alcohol series $(70 \%, 80 \%$, $90 \%$, and $100 \%$ ) and were embedded in paraffin. Seven $10-\mu \mathrm{m}$ thick sections were prepared from these paraffin blocks, and the clearest section from each sample for each treatment was examined under a microscope. The maximum diameter of individual cells from the maximum transverse diameter in each sample was measured (Fig. 3).

Sugar analysis. The other strips, each measuring $\approx 15 \mathrm{~mm}$, were serially sampled across the diameter of the disk using the same sharp table knife. Except for the two outermost RPs at both ends, all of the RPs of the fruits 16 and 42 DAA were used for sugar

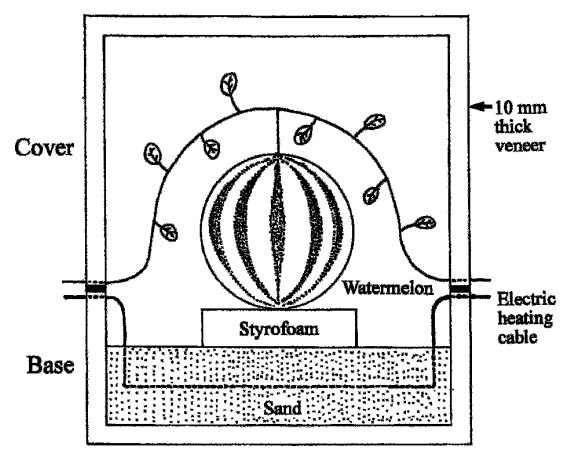

Fig. 1. An illustration of the heating apparatus for watermelon fruit. 


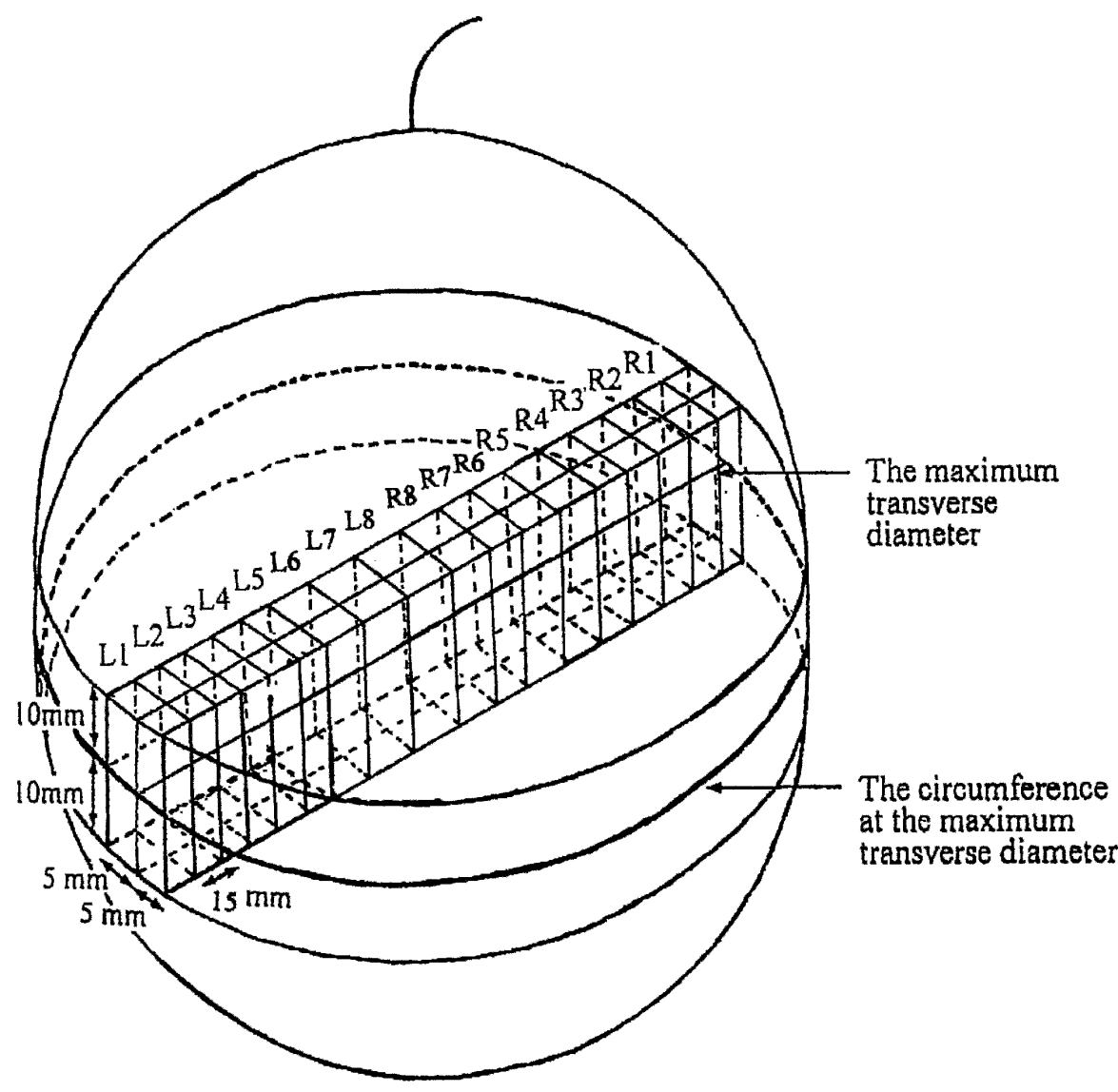

Fig. 2. An illustration of the collection of rectangular parallelepipeds for the determination of sugar content in watermelon fruit. This is an example of untreated fruit at $42 \mathrm{~d}$ after anthesis.

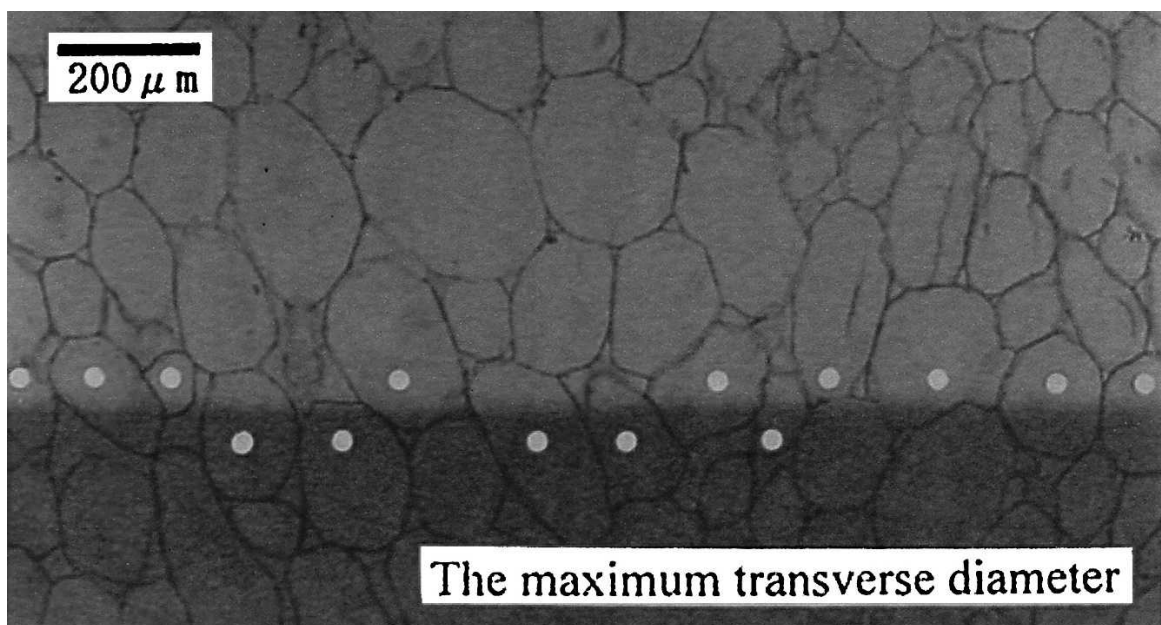

Fig. 3. Method used for measuring the size and number of cells in melon fruit. White dots indicate the actual cells measured.

analysis. All of the RPs were wrapped in cheesecloth and squeezed using pincers to extract the juice. The juice was diluted 10 times with distilled water. The solution was centrifuged at $8000 \times g$ for $15 \mathrm{~min}$ before being filtered through a $0.45-\mu \mathrm{m}$ PTEF hydrophilic filter (Millipore, Bedford, MA). Twenty microliters of the filtrate was injected into a high-performance liquid chromatography (HPLC) apparatus (LC-10ADvp; Shimadzu, Kyoto, Japan) fitted with a refractive index detector (RID-10A; Shimadzu) perature of the heating treatment was $\approx 6{ }^{\circ} \mathrm{C}$ higher at $18^{\circ} \mathrm{C}$.

The weight of heat-treated fruit at the end of heating treatment, 16 DAA, was $5.2 \mathrm{~kg}, 1.3$ $\mathrm{kg}$ greater than that of the control. However, fruit weight at harvesting, 42 DAA, was almost the same in both treatments.

Cells of all portions of the heat-treated fruit 16 DAA was much larger than those of the control (Fig. 4). Although cell size of the control was $\approx 300 \mu \mathrm{m}$, cell size of the heattreated fruit was $320 \mu \mathrm{m}$ or more. Especially, the cells in the outermost RPs of the heattreated fruit were $80 \mu \mathrm{m}$ or more larger than those of the control.

At 16 DAA, the number of RP with a sucrose content of $2 \mathrm{~g} \cdot \mathrm{L}^{-1}$ or more was six and nine in control and heat-treated fruit, respectively (Fig. 5). The number of RPs with a glucose and fructose content of $40 \mathrm{~g} \cdot \mathrm{L}^{-1}$ or more was two and four and three and seven in control and heat-treated fruit, respectively. Mean fruit sucrose, glucose, and fructose contents at 16 DAA did not differ between control and heat-treated fruit. At 42 DAA, sucrose content in the outer RPs was low in control but high in heat-treated fruit (Fig. 6). Sucrose contents of L3 and R3 (see Fig. 2 for explanation of symbols) in control fruit were $23.6 \mathrm{~g} \cdot \mathrm{L}^{-1}$ and $18.7 \mathrm{~g} \cdot \mathrm{L}^{-1}$, but $39.1 \mathrm{~g} \cdot \mathrm{L}^{-1}$ and $29.7 \mathrm{~g} \cdot \mathrm{L}^{-1}$ in heat-treated fruit, respectively. The number of RPs with a sucrose content of $40 \mathrm{~g} \cdot \mathrm{L}^{-1}$ or more was five in control fruit, but 11 in heat-treated fruit. In contrast, glucose and fructose contents in each RP were lower in heat-treated than control fruit. Mean sucrose content of the heat-treated fruit was $53 \mathrm{~g} \cdot \mathrm{L}^{-1}, 32 \%$ greater than that of the control. Glucose and fructose content was lower in heat-treated fruit than in control.

\section{Discussion}

Heat-treated fruit at the end of heating treatment, at 16 DAA, was heavier than the control, but fruit weight at harvesting, 42 DAA, was the same in both treatments. Minimum temperature of the heat treatment was $\approx 18{ }^{\circ} \mathrm{C}, 6{ }^{\circ} \mathrm{C}$ higher than that of the control. Optimum temperature for growth of watermelon is 25 to $30^{\circ} \mathrm{C}$ during the day and

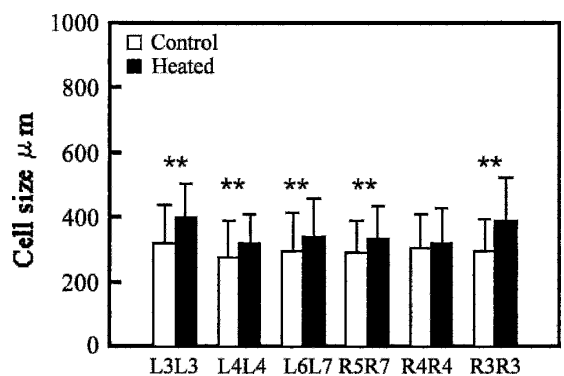

Fig. 4. Effects of heating fruit during night on cell size at several portions of watermelon $16 \mathrm{~d}$ after anthesis (DAA). Refer to Figure 2 for the meaning of symbols under the figure. Heated: fruits were heated for $10 \mathrm{~d}$ from 6 to $16 \mathrm{DAA}$. Vertical bars are SD $(\mathrm{n}=81 \approx 233)$. **Significantly different at $P<0.05$ by $t$ test. 

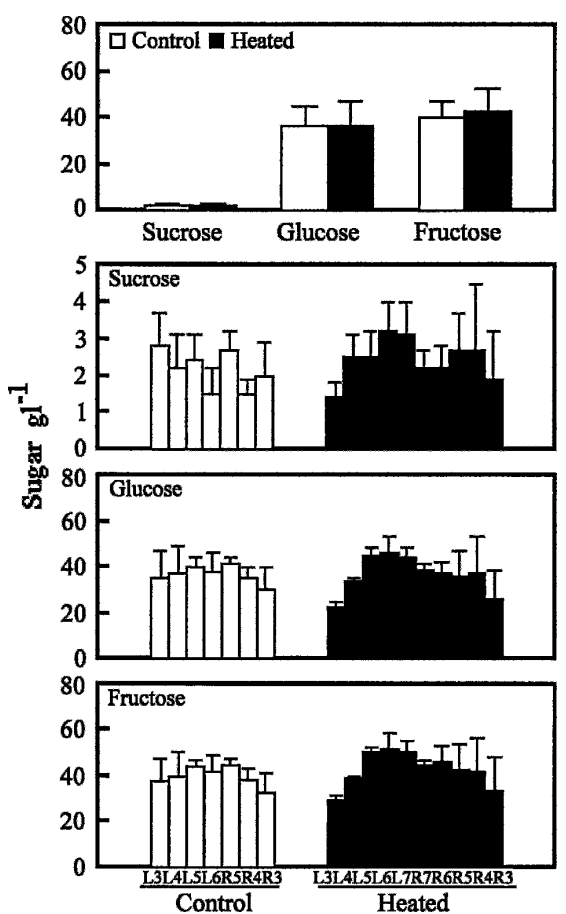

Fig. 5. Effects of heating fruit during night on fruit sugar content. Heated: fruits were heated for $10 \mathrm{~d}$ from $6 \mathrm{~d}$ after anthesis (DAA) to 16 DAA. Fruits were collected at 16 DAA. Uppermost figure: mean content of all the parallelepipeds (RPs) in each sugar of each treatment. Vertical bars are SD $(n=21$ and 30). Lower three figures: sugar content in each rectangular RP. Vertical bars are SD $(n=3)$. Refer to Figure 2 for the meaning of symbols.

16 to $20{ }^{\circ} \mathrm{C}$ during the night (Saito, 1991). Cell division in watermelon fruit stops at 6 DAA (Kano, 1993). In this experiment, watermelon fruits were treated after 6 DAA. Growing melon plants at higher temperature (Kano and Fukuoka, 2006; Suzuki et al., 1993) and heat treatment of melon fruit itself (Kano, 2006) increase the number of larger cells and produce larger fruits. Therefore, it is suggested that nighttime heat treatment of watermelon fruit results in larger fruit resulting from the acceleration of cell enlargement.

Cells of all portions of the heat-treated fruit were much larger than those of the control. Especially, the cells in the outermost RPs of the heat-treated fruit were $80 \mu \mathrm{m}$ or more larger than those of the control. Cells grow larger in melon cv. Earl's Favorite with anthesis on 6 Aug. than in fruit with anthesis on 20 June and grow larger in the higher night temperatures (Masuda, 1970). Higher fruit temperatures in melons covered with heating apparatus results in the predominance of larger cells (Kano, 2006). Growing melon fruit at higher temperature (Kano and Fukuoka, 2006; Suzuki et al, 1993) and heat

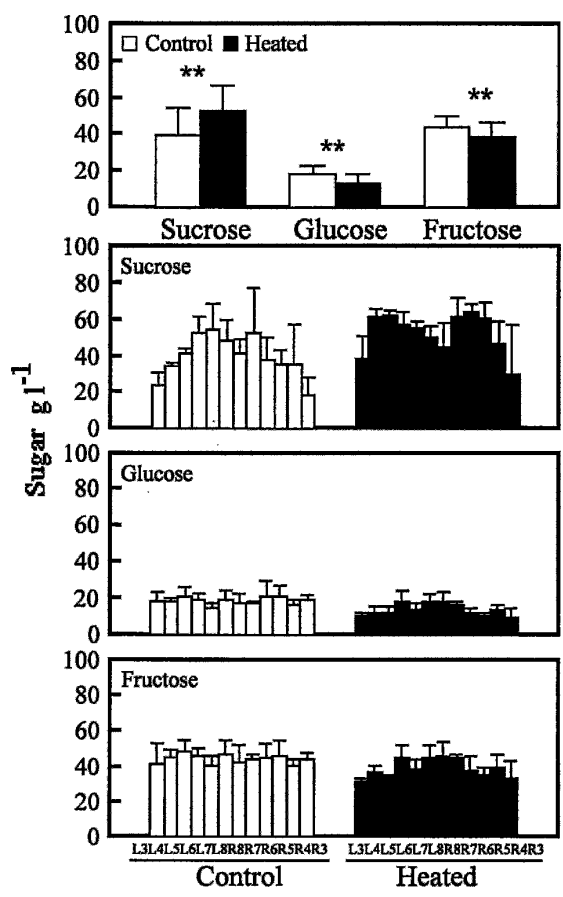

Fig. 6. Effects of heating fruit during night on sugar content in watermelon fruit. Heated $=$ fruits were heated for $10 \mathrm{~d}$ from $6 \mathrm{~d}$ after anthesis (DAA) to 16 DAA. Fruits were collected at 42 DAA. Uppermost figure: mean content of all of the parallelepipeds (RPs) in each sugar of each treatment. Vertical bars are SD $(\mathrm{n}=36)$. **Significantly different at $P<0.01$ by $t$ test. Lower three figures: sugar content in each rectangular RP. Vertical bars are SD $(n=3)$. Refer to Figure 2 for the meaning of symbols.

treatment of fruit (Kano, 2006b) increases the number of larger cells and sucrose content. From these results, it is reasonable to consider that heating fruit during night causes cell enlargement in watermelon fruit. Furthermore, it is suggested that the temperature at the outer portion during night is much higher than that at the inner portion of watermelon with reference to the report that the outer portion of watermelon is most susceptible to ambient temperature (Kano, 2004). Therefore, we suppose that the reason for larger cells at the outer portion than at the inner portion is owing to a higher temperature at the outer portion during the night.

The increase of the number of large cells by 4 -chlorophenoxyaceticacid treatment to melon fruit results in the rise of the suction force of cells, which promotes the active import of sucrose from an early stage of fruit development (Kano, 2002). An increasing number of larger cells of melon fruit grown under higher temperature brings about active sucrose accumulation, resulting in high sucrose content in the fruit (Kano, 2006).
The rate of translocation of ${ }^{14} \mathrm{C}$-photosynthates to tomato fruits increases when the fruit temperature is higher (Walker and Ho, 1977). Sucrose accumulates preferentially in melon fruit, which has a great number of larger cells, but glucose and fructose accumulate preferentially in grape berries, which has a large number of smaller cells (Kano, 2007). These results point out that sucrose accumulates actively in larger cells. Therefore, higher sucrose content in the outer portion of heat-treated watermelon is attributable to the promotion of sucrose accumulation owing to progressive cell enlargement in the outer portion.

From these results we conclude that nighttime heat treatment of watermelon fruit results in early enlargement of cells in the outer portions. The early cell enlargement in the outer portions causes active sucrose accumulation, resulting in a high sucrose content therein.

\section{Literature Cited}

Elmstrom, G.W. and P.L. Davis. 1981. Sugars in developing and mature fruits of several watermelon cultivars. J. Amer. Soc. Hort. Sci. 106:330-333.

Kano, Y. 1993. Relationship between the occurrence of hollowing in watermelon and the size and the number of fruit cells and intercellular air spaces. J. Jpn. Soc. Hort. Sci. 62:103-112.

Kano, Y. 2002. Relationship between sucrose accumulation and cell size in 4-CPA-treated melon fruits (Cucumis melo L.). J. Hort. Sci. Biotechnol. 77:546-550.

Kano, Y. 2004. Effects of summer day-time temperature on sugar content in several portions of watermelon fruit (Citrullus lanatus). J. Hort. Sci. Biotechnol. 79:142-145.

Kano, Y. 2006. Effects of heating fruit on cell size and sugar accumulation in melon fruit $(\mathrm{CuCu}$ mis melo L.). HortScience 41:1431-1434.

Kano, Y. 2007. Comparison of cell size and kind of sugars accumulated in grape berries vs. melon fruits. Environ. Control Biol. 45:95-101.

Kano, Y. and N. Fukuoka. 2006. Comparison of cell size and sugar accumulation in melon fruit (Cucumis melo L.) between early and late sowing in summer. Environ. Control Biol. 44:93-102.

Masuda, T. 1970. Studies on the development of melon fruits. Kyoto Univ. Kyoto, Japan. PhD Diss.

Saito, T. 1991. Watermelon, p. 131-134. In: Sosaiengei no jiten (Cyclopedia of olericulture). Asakurashoten, Tokyo, Japan.

Suzuki, M., M. Nakahara, and N. Asano. 1993. Relationship of seeding time, especially cumulative temperature, and vegetative growth of netted melon (Cucumis melo L. var. reticulatus) cultivars in retarded cultivation. Bull. Hort. Institute Ibaraki Agr. Center. 1:57-64.

Walker, A.J. and L.C. Ho. 1977. Carbon translocation in the tomato: Effects of fruit temperature on carbon metabolism and the rate of translocation. Ann. Bot. (Lond.) 41:825-832. 